\title{
THE WORK EFFECTIVENESS OF SHIP CREW NATIONAL SHIPPING IN INDONESIA
}

\author{
Prasadja Ricardianto ${ }^{1}$, Adenan Suhalis ${ }^{2}$,Francis Tanri ${ }^{3}$ \\ 1. STMT Trisakti, 2. STMT Trisakti, 3. STMT Trisakti \\ $\triangle$ corresponding author: ricardianto@yahoo.com
}

\begin{abstract}
The aim of this research is to analyze the influence of leadership style, and the employee engagement on the work effectiveness of ship crew of PT Pelayaran Nasional Indonesia (PELNI). PELNI is a state-owned company running a shipping business. The research survey is done toward 95 ship crew using a sampling technique through clusters of observation unit or what-so-called Cluster Systematic Sampling from the whole population as many as 375 ship crew on pasenger ships at Port of Tanjung Priok. The respondents are the ship crew of the analysis unit under the leadership of ship officers under the Captain. The research methodology uses a quantitative associative approach with the method of path analysis. The results of this study indicate that leadership style, and the employee engagement have direct and positive correlation with work effectiveness. The benefit for PELNI is that through the improvement of the officers' leadership style and employee engagement, the work effectiveness of each ship crew will improve. The novelty of this study is escpecially on the model of employee engagement and the ship crew's work effectiveness in the national shipping. The output of this study is that every change in the quality of ship officer's leadership style and employee engagement will directly and positively influence the work effectiveness of PELNI's ship crew.
\end{abstract}

Keywords: leadership style, employee engagement, work effectiveness, ship officer, ship crew

\section{Introduction}

Based on the report, the capability of PELNI's employees in the period of 2011 to 2015 can be seen as an example of assessment on the officers like Navigator and Machinist, generally with good and fair scores. There have been ever an assessment on one of the Machinists; he got very poor scores. The problem of employee engagement is on the degree of ship crew loyalty. For example, when an employee feels the company does not provide sufficient welfare since their salaries are generally still lower than those from private shipping companies. 
In a study of ship crew previously investigated in connection with safety in the operational performance of a passenger ship (Lasse \& Fatimah, 2016). In the previous study on leadership style, the increase of wrong and other deviant behaviours in the workplace has disastrous effects for organisations, such as lowered effectiveness, escalated costs and the organisation's declining reputation (Engelbrecht, 2017). The use of variable effectiveness with Path Analysis method has also been done (Tantri, Gunawan, \& Ruminda, 2015). The higher the price and the quality of services will simultaneously increase the customer satisfaction (Haryono, Wahyuni, \& Darunanto, 2016).

Bosiok indicated a significant correlation between the latent dimensions of the creativity construct and those of autocratic, democratic and liberal leadership styles (Bosiok \& Sad, 2013). In adition, leadership style is the most prevalent factor that influences employees' attitudes and behaviors including organizational commitment (Clark, Hartline, \& Jones, 2009).

Engagement is condition where an individual is emotionally and intellectually committed to an organization which is measured based on three main behaviours; say, stay and strive (Development, Dimensions, \& International, 2005). Engagement is frequently shown when an individual shows the behaviour related to talking positively about the organization (say), having a wish to be a part of the organization (stay), and willingness to make extra efforts that contribute to the organization's success (strive) (Hewitt, 2012).

Five dimensions of work effectiveness consist of quality, quantity, punctuality, effectiveness and independence (Robbins \& Coulter, 2013). Quality of service has been conducted research on permanent employees and marine employees of a shipping company (Kadarisman, Sudewo, \& Pahala, 2016). Quality of service can also significant effect on other variables such as loyalty customer (Marina, Darmawati, \& Setiawan, 2014). Service quality have 
a significant relationship either partially or simultaneously with customer satisfaction (Pangihutan, Thamrin, \& Suparman, 2016).

Work effectiveness has four short term criteria, namely quality, productivity, efficiency and satisfaction. For middle term the criteria are quality, ability to adapt, efficiency and satisfaction, whereas the long term criteria are quality and sustainability (Ivancenvich, Konopaske, \& Matteson, 2007). Work effectiveness also has five dimensions, namely quantity, quality, reliability, presence, and ability to collaborate (Mathis \& Jackson, 2009). Effective service in the field of transportation is covering the right target and time (Kadarisman \& Pahrudin, 2014).

In adition, work effectiveness is divided into six classifications, namely deadline fulfillment, work accuracy, degree of complaint from customers, superordinates and other departments, loyalty or compliance with quality standards, obedience to the approved budget, and productivity (Mullins, 2013). Based on these theories, it can be conceptualized in a concrete way that work effectiveness is the effective performance of an employee based on quality, work quantity, punctuality, satisfaction, and work productivity taken advantage to achieve the real obectives.

Initially, the concept of leadership style is developed by (Bass, 1997, Bass \& Riggio, 2006), into four dimensions, namely Idealized Influence, Inspirational Motivation, Intelectual Stimulation, and Individual Consideration. Three groups of leadership style from staff up to managerial level and focus on the strength: autoctratic, democratic and Laizes-faire. There are many leadership styles and none is better than the other in any situation (Mullins, 2013, Robbins \& Coulter, 2013). For higher or lower level, a leader may be autocratic or democratic, controller or enabler, job oriented or focus on people (Armstrong \& Taylor, 2014). Based on these theories, it can be conceptualized in a concrete way that a better leadership style is autocratic or democratic, ideal 
influence, inspirational motivation, intellectual stimulation, and individual consideration.

Based on the research dimension, employee engagement is divided into three characteristics, like "A condition of being positive, satisfying, related to mind works specified by vigour, stay and strive" (Maslach, Schaufeli, \& Leiter, 2001). Employee engagement is added, developed through general behaviour in the three-dimension aspect; say, stay and strive. Kenexa offers an engagement index called Kenexa Index from the employee engagement in four dimensions; pride, satisfaction, advocacy, and retention (Development, Dimensions, \& International, 2005, and Hewitt, 2013). Engagement, satisfaction, and enthusiasm of an individual to work are three dimensions of Engagement (Kreitner \& Kinicki, 2014).

\section{Method}

The approach used in this research is Path Analysis and some steps such as the quality of causality design, validity and reliability tests, normality and linearity. The sampling technique is through clusters of observation unit or socalled Cluster Systematic Sampling. The author uses two methods; qualitative data in the form of questionnaires and quantitative data in the form of score answers, as well as the use of data analysis techniques through weighting Likert Scale same thing ever done by research on crew (Lasse \& Fatimah, 2016). This in PELNI is more known as Rating system. Yamane formula is used for the sample of 95 ship crew of the total 375 ship crew. The result from questionnaires is considered reliable and valid in the previous test on 30 respondents.

The results of validity tests on the instruments of work effectiveness $(\mathrm{Y})$, leadership style $\left(\mathrm{X}_{1}\right)$, and employee engagement $\left(\mathrm{X}_{2}\right)$ indicate that the items of question are mostly valid. The results of reliability tests on all 
variables are above 0,9 or having high reliability. The hypothetical tests in the path analysis are carried out both simultaneously and partially.

Overall, Path Analysis Conceptual Model in this study is as follows:

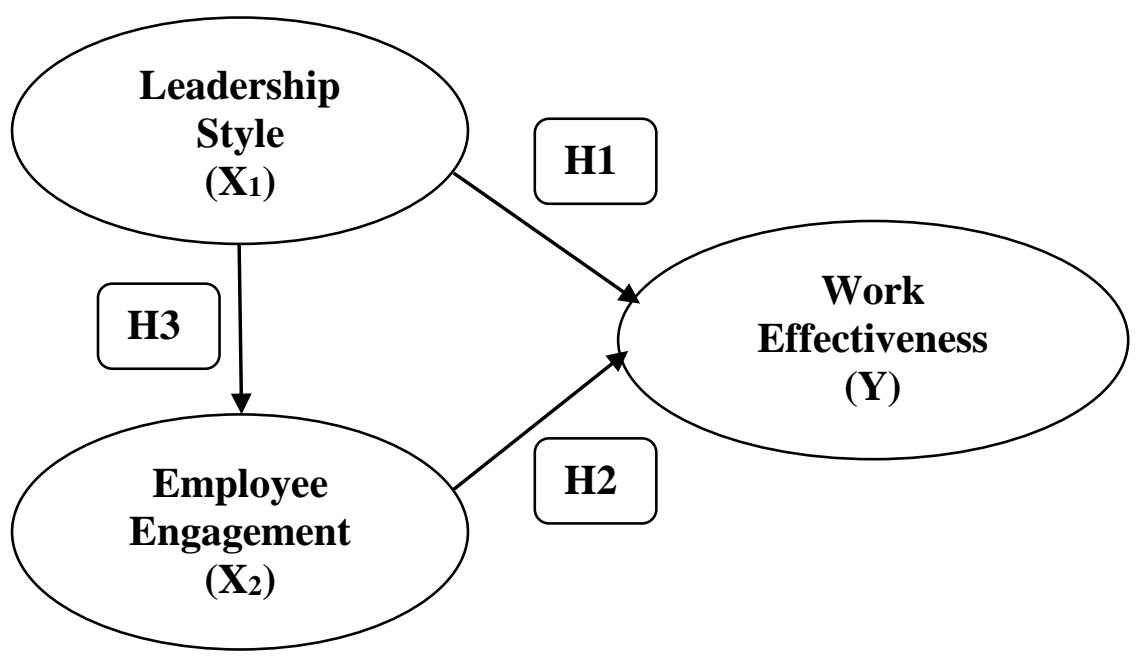

Figure 1. Conceptual Frame

This research uses path analysis method, and some researches using path analysis method have also been done before to test the conceptual frame. Using path analysis for the linkages between leadership approaches and coordination effectiveness (Akhtar \& Khan, 2015). Further study, using metaanalytic estimation and path analysis, is needed to test whether the construct of employee engagement shows an incremental validity in the prediction of employee's effectiveness (Mackay, Allen, \& Landis, 2017).

\section{Discussion and Result}

\section{Normality Test}

The data of 95 research samples should be fulfilled in the path analysis through normality test of estimated error of each variable. The first requirement that should be fulfilled in path analysis is that the estimated error sample must be sourced from the population having normal distribution. In the significance

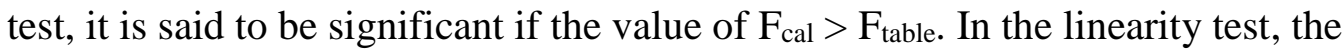


regression equation is said to be linear if the value of $F_{c a l}<F_{\text {table, and vice }}$ versa. Based on the calculation, it is found $\mathrm{L}_{c a l}\left(\mathrm{~L}_{\max }\right)$ and the critical value of $\mathrm{L}$ with $\mathrm{n}=95$ and $\alpha=0,05 . \mathrm{L}_{\text {cal }}<\mathrm{L}_{\text {table }}$ means that $\mathrm{H}_{0}$ is accepted. So, it can be concluded that the study on these three hypothesis are normally distributed.

\section{Significance Test and Regressive Linearity Test}

Significance test and regressive linearity test in this study are carried out using variance analysis and result in the value of $F$ as parameter. In the significance test, it is said to be significant if the value of $F_{c a l}>F_{t a b l e}$, and vice versa. In the linearity test, the regression equation is said to be linear if the value of $\mathrm{F}_{\mathrm{cal}}<\mathrm{F}_{\text {table, }}$ and vice versa.

The summary of calculation is presented in Table 1 .

Table 1. Summary of Significance Test and Linearity Test Results

\begin{tabular}{|c|c|c|c|c|c|}
\hline \multirow{2}{*}{ Regression } & \multirow{2}{*}{ Equation } & \multicolumn{2}{|c|}{ Significance Test } & \multicolumn{2}{|c|}{ Linearity Test } \\
\cline { 3 - 6 } & & $\mathbf{F}_{\text {cal }}$ & F table & $\mathbf{F}_{\text {cal }}$ & $\mathbf{F}_{\text {table }}$ \\
\hline $\mathrm{Y}$ atas $\mathrm{X}_{1}$ & $\mathrm{Y}=4,438+0,727 \mathrm{X}_{1}$ & 1283,75 & 3.94 & 1,034 & 1,73 \\
\hline $\mathrm{Y}$ atas $\mathrm{X}_{2}$ & $\mathrm{Y}=-10,344+1,004 \mathrm{X}_{2}$ & 1030,54 & 3.94 & 1,633 & 1,73 \\
\hline $\mathrm{X}_{2}$ atas $\mathrm{X}_{1}$ & $\mathrm{X}_{2}=20,660+0,688 \mathrm{X}_{1}$ & 1011,17 & 3.94 & 1,563 & 1,68 \\
\hline
\end{tabular}

\section{Hypothetical Test}

The conclusion can be compared with the hypothesis proposed in this study. From the three hypotheses proposed, based on the result of research, three null hypotheses $\left(\mathrm{H}_{0}\right)$ are rejected and alternative hypotheses $\left(\mathrm{H}_{1}\right)$ are accepted as explained in Table 2. 
Table 2. Summary of Hypothetical Test Results

\begin{tabular}{|c|c|c|c|c|c|}
\hline No & Hypotheses & $\begin{array}{l}\text { Statistical } \\
\text { Test }\end{array}$ & $\mathbf{t}_{\text {cal }}$ & $\begin{array}{l}\text { Decision } \\
\mathbf{H}_{\mathbf{o}}\end{array}$ & Conclusion \\
\hline 1. & $\begin{array}{l}\text { Leadership Style }\left(\mathrm{X}_{1}\right) \\
\text { directly influences the } \\
\text { variable of Work } \\
\text { Effectiveness (Y) }\end{array}$ & $\begin{array}{l}\mathrm{H}_{0}: \rho_{\mathrm{y} 1} \leq 0 \\
\mathrm{H}_{1}: \rho_{\mathrm{y} 1}>0\end{array}$ & 6,98 & $\begin{array}{l}\mathrm{H}_{\mathrm{o}} \text { is } \\
\text { rejected }\end{array}$ & $\begin{array}{l}\text { It has a positive } \\
\text { direct influence }\end{array}$ \\
\hline 2. & $\begin{array}{l}\text { Employee Engagement } \\
\left(\mathrm{X}_{2}\right) \text { directly influences } \\
\text { the variable of Work } \\
\text { Effectiveness (Y) }\end{array}$ & $\begin{array}{l}\mathrm{H}_{0}: \rho_{\mathrm{y} 2} \leq 0 \\
\mathrm{H}_{1}: \rho_{\mathrm{y} 2}>0\end{array}$ & 4,78 & $\begin{array}{l}\mathrm{H}_{\mathrm{o}} \text { is } \\
\text { rejected }\end{array}$ & $\begin{array}{l}\text { It has a positive } \\
\text { direct influence }\end{array}$ \\
\hline 3. & $\begin{array}{l}\text { Leadership Style }\left(\mathrm{X}_{1}\right) \\
\text { directly influences the } \\
\text { variable of Employee } \\
\text { Engagement }\left(\mathrm{X}_{2}\right)\end{array}$ & $\begin{array}{l}\mathrm{H}_{0}: \rho_{21} \leq 0 \\
\mathrm{H}_{1}: \rho_{21}>0\end{array}$ & 31,7 & $\begin{array}{l}H_{o} \text { is } \\
\text { rejected }\end{array}$ & $\begin{array}{l}\text { It has a positive } \\
\text { direct influence }\end{array}$ \\
\hline
\end{tabular}

The summary of the calculated value of path coefficient $\left(\rho Y_{1}, \rho Y_{2}, \rho_{21}\right)$ which are significant as shown in Table 3.

Table 3. Results of Path Coefficient Calculation and Test

\begin{tabular}{|ccccl|}
\hline No & Path Coefficient & tcal $_{\text {cal }}$ & table & Remarks \\
\hline 1 & $\rho \mathrm{Y}_{1}=0,957$ & 31,799 & 1,666 & Significant \\
2 & $\rho \mathrm{Y}_{2}=0,593$ & 6,981 & 1,666 & Significant \\
3 & $\rho_{21}=0,399$ & 4,780 & 1,666 & Significant \\
\hline
\end{tabular}

The structural model of path and the result of path analysis calculation as well as the value of correlation (r) are as shown in Figure 2. 


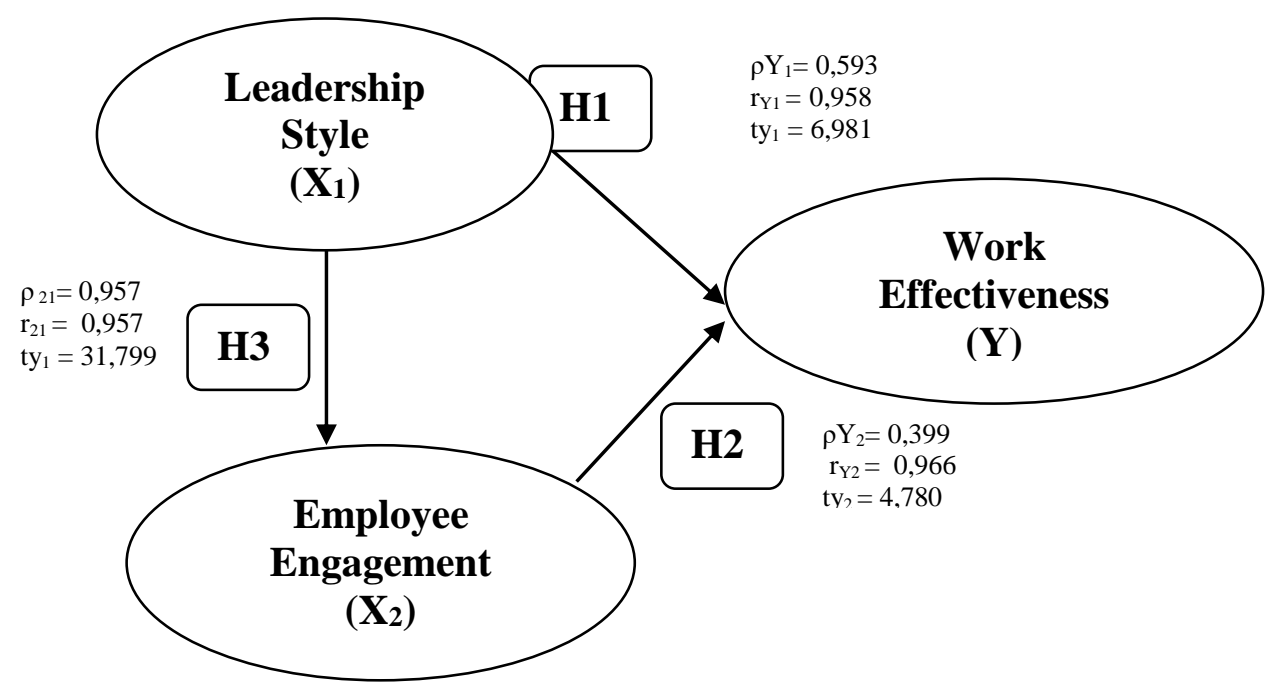

Figure 2. Model of Structural Correlation among Variables

The findings from this research are resulted from 95 ship crew who work at three vessels. Overall, the result of hypothetical test indicates that the model of Structural Correlation among Variables has significant influences.

\section{Hypothesis 1. Leadership Style has a positive direct effect on Work Effectiveness}

Based on the structural equation explained before, leadership style has positive direct influence on Work Effectiveness; the result of analysis shows that coefficient $\rho Y_{1}$ is 0,593 . from the test it finds $t_{\text {cal }}>t_{\text {table }}$ meaning 6,981> 1,666, indicating $\mathrm{H}_{0}$ is rejected and $\mathrm{H}_{1}$ is accepted.

The study on the theory of leadership style supports employee's work effectiveness. The result of this study supports the opinion that with encouragement and inspiration, a leader should have a leadership style that can give examples of good work in order to increase work effectiveness (Dubrin, 2013). Leadership style is replicated in attitude and behaviour but, in turn, this is the result of complex interaction between the way of thinking and individual nuance (Khan \& Nawaz, 2016). Thus, the result of this study is in accordance with the research theory and the result of previous relevant study. It means, 
leadership style gives a positive direct influence on performance effectiveness in an optimal way.

\section{Hypothesis 2. Employee Engagement has a positive direct effect on Work Effectiveness}

Based on the structural equation mentioned before concerning the employee engagement directly influencing work effectiveness, then the result analysis indicates that coefficient $\mathrm{pY}_{2}$ is 0,339 . From the test, it is found $\mathrm{t}_{\mathrm{cal}}>$ $t_{\text {table }}$ meaning that $4,780>1,666$, indicating that $\mathrm{H}_{0}$ is rejected and $\mathrm{H}_{1}$ is accepted.

Theoretical study states that employee engagement supports Work effectiveness. High employee engagement will result in high performance, as stated by Sparrow in (Armstrong \& Taylor, 2014). Another result indicates that leadership and organizational equity are the most significant drivers of employee engagement (Dajani, 2015). Thus, the result of this study is in accordance with the research theory and the previous relevant study. It means engagament has a positive direct influence on Work effectiveness.

\section{Hypothesis 3. Leadership style has a positive direct influence on Employee Engegament}

Based on the structural equation explained before, leadership style has positive direct influence on Work Effectiveness; the result of analysis shows that coefficient $\rho Y_{1}$ is 0,957 . From the test, it is found the positive direct influence of leadership style on employee engagement $\left(X_{2}\right)$ at $t_{c a l}>t_{\text {table }}$ meaning $31,799>1,666$, indicating that $\mathrm{H}_{0}$ is rejected and $\mathrm{H}_{1}$ is accepted.

Theoretical study states leadership style supports employee engagement. The result of this study supports the theory (Armstrong, 2009), that leaders must have a wisdom which encourages employee engagement. In the previous relevant study, considering the importance of a leader for an 
organization, this study examines the correlation between leadership style (autocratic, democratic and laissez-faire) and employee engagement in construction industry (Yao, Woan, Li, \& Ahmad, 2017). Thus, the result of this study is in accordance with the theoretical study and previous relevant studies. It means leadership style have a positive direct influence on employee engagement.

\section{Conclusion}

The result of this research shows the positive direct influence of leadership style and employee engagement on the ship crew's work effectiveness. It is also an effort to improve the ship crew's work effectiveness by improving quality, quantity, punctuality, job satisfaction and work productivity of leadership style and employee engagement variables. It is noted that some ship officers having democratic style do not much consider the suggestions from ship crew before making decisions, do not much encourage employee participation in determining the working method and the objectives to be achieved.

The results also show engagement of ship crew that has a positive attitude, engagement, commitment, enthusiasm to his work directly affect the effectiveness of work. Employee engagement promotes effectiveness in an organization by increasing morale (vigor), dedication, absorption and loyalty (stay). Employed employees who are comfortable with their work will be concerned about their organization and work to contribute to its success.

\section{References}

Akhtar, \& Khan. (2015). The linkages between leadership approaches and coordination effectiveness: A path analysis of selected New Zealand-UK International agri-food supply chains. British Food Journal, 117(1), 443460. https://doi.org/https://doi.org/10.1108/BFJ-12-2013-0357

Armstrong. (2009). Amstrong's Handbook of Human Resource Management Practice (11nd Editi). London and Philadelphia.: Kogan Page Limited. Retrieved

from 
https://books.google.co.id/books/about/Armstrong_s_Handbook_of_Perfor mance_Mana.html?id=wtwS9VG-p4IC\&redir_esc=y

Armstrong, \& Taylor. (2009). Amstrong's Handbook of Human Resource Management Practice (11th Editi). London and Philadelphia.: Kogan Page Limited. https://doi.org/10.1177/030913258901300105

Armstrong, \& Taylor. (2014). A handbook of human resource management practice. Human Resource Management (13th Editi). Kogan Page.

Bartuševičienè, \& Sakalytė. (2013). Organizational assessment: effectiveness vs. efficiency. Social Transformations in Contemporary Society, 1(1), 4553. https://doi.org/10.3923/sscience.2017.984.988

Bass. (1997). Does the transactional-transformational leadership paradigm transcend organisational and international boundaries. American Psychologist, 52(2).

Bass, \& Riggio. (2006). Transformasional Leadership. London, New Jersey.: Lawrence Erlabaum Associates Publishers.

Bosiok, \& Sad. (2013). Leadership styles and creativity. Online Journal of Applied Knowledge Management, 1(2), 64-77.

Clark, Hartline, \& Jones. (2009). The effects of leadership style on hotel employees' commitment to service quality. Cornell Hospitality Quarterly, 50(2), 209-231.

Dajani. (2015). The Impact of Employee Engagement on Job Performance and Organisational Commitment in the Egyptian Banking Sector. Journal of Business and Management Sciences, 3(5), 138-147. https://doi.org/https://doi.org/10.12691/jbms-3-5-1

Development, Dimensions, \& International. (2005). Development Dimensions In Employee Engagement: The Key To Realizing Competitive Advantage.

Dubrin. (2013). Essentials of Management. Essentials of Management (9th Editio). USA: South-Western, USA: Cengage Learning.

Ekaterini. (2010). The Impact of Leadership Styles on Four Variables of Executives Workforce. International Journal of Business and Management, 5(6). https://doi.org/http://dx.doi.org/10.5539/ijbm.v5n6p3

Engelbrecht. (2017). Effect of ethical leadership and climate on effectiveness. SA Journal of Human Resource Management, 15(1), 1-8. https://doi.org/https://doi.org/10.4102/sajhrm.v15.781

Eo, Kim, \& Lee. (2014). Path analysis of empowerment and work effectiveness among staff nurses. Asian Nursing Research, 8(1), 42-48. https://doi.org/http://dx.doi.org/10.1016/j.anr.2014.02.001 1976-1317

Ertureten, Cemalcilar, \& Aycan. (2013). The relationship of downward mobbing with leadership style and organizational attitudes. Journal of Business Ethics, 116(1), 205-216.

Hanifah, Susanthi, \& Setiawan. (2014). The Effect of Leadership Style on Motivation to Improve the Employee Performance. Jurnal Manajemen Transportasi \& Logistik, 1(3), 221-226. https://doi.org/http://dx.doi.org/10.25292/j.mtl.v1i3.20 
Haryono, Wahyuni, \& Darunanto. (2016). Analisis Pengaruh Harga dan Kualitas Layanan terhadap Kepuasan Pelanggan P. Jurnal Manajemen Bisnis Transportasi Dan Logistik, 2(2), 201-219. Retrieved from http://library.stmt-trisakti.ac.id/jurnal/index.php/JMBTL/article/view/47

Hewitt. (2012). Trends in Global Employee Engagement.

Hewitt. (2013). Employee engagement higher at double digit growth companies.

Ivancenvich, Konopaske, \& Matteson. (2007). Perilaku dan Manajemen Organisasi. (G. Gania, Ed.), Perilaku dan Manajemen Organisasi (Edisi Ketu). Jakarta: Penerbit Erlangga.

Kadarisman, \& Pahrudin. (2014). Pemberdayaan Pegawai dalam Rangka Peningkatan Kualitas Pelayanan. Jurnal Manajemen Transportasi Dan Logistik, $\quad 1(1)$, $15-29$. https://doi.org/http://dx.doi.org/10.25292/j.mtl.v1i1.4

Kadarisman, Sudewo, \& Pahala. (2016). Pemberdayaan Karyawan Dan Kualitas Pelayanan Pada Perusahaan Pelayaran. Jurnal Manajemen Transportasi \& Logistik, 3(3), 339-348. https://doi.org/http://dx.doi.org/10.25292/j.mtl.v4i2.97

Khan, \& Nawaz. (2016). The Leadership Styles And The Employees Performance: A Review. Gomal University Journal of Research [GUJR], 32(2).

Kreitner, \& Kinicki. (2014). Perilaku Organisasi (Edisi 9). Jakarta: Salemba Empat.

Lasse, \& Fatimah. (2016). Pelatihan Keselamatan bagi Anak Buah Kapal. Jurnal Manajemen Bisnis Transportasi Dan Logistik, 2(2), 257-266. Retrieved from http://library.stmttrisakti.ac.id/jurnal/index.php/JMBTL/article/viewFile/51/52

Mackay, Allen, \& Landis. (2017). Investigating the incremental validity of employee engagement in the prediction of employee effectiveness: A meta-analytic path analysis. Human Resource Management Review, 27(1), 108-120. https://doi.org/10.1016/j.hrmr.2016.03.002

Marina, Darmawati, \& Setiawan. (2014). The Effect of Service Quality on Customers Loyalty in Full Service Airlines. Jurnal Manajemen Transportasi \& Logistik, https://doi.org/http://dx.doi.org/10.25292/j.mtl.v1i2.15

Maslach, Schaufeli, \& Leiter. (2001). Job burnout. Annual review of psychology,. Annual Review of Psychology, 52(1), 397-422.

Mathis, \& Jackson. (2009). Human Resource Management. (Edisi kese). Jakarta: Salemba Empat.

Mullins. (2013). Management and Organizational Behavior (11th editi). Pearson Education Limited.

Pangihutan, Thamrin, \& Suparman. (2016). Services Quality Of Ship Agency Services And Interpersonal Communication In Shipping Companies. Jurnal Manajemen Transportasi \& Logistik, 3(2). 
https://doi.org/http://dx.doi.org/10.25292/j.mtl.v3i2.102

Robbins, \& Coulter. (2013). Management. Management. (12th ed.). Boston: Pearson.

Saul, Kim, \& Kim. (2015). Leadership and Employee Engagement, Proposing Research Agendas Through a Review of Literature. Saul Kim Kim, 14(1). https://doi.org/https://doi.org/10.1177/1534484314560406

Schaufel, \& Bakker. (2004). Utrecht Work Engagement Scale: Preliminary manual. Utrecht University, Occupational Health Psychology Unit.

Schaufeli, Salanova, Alez-ro, G., \& Bakker. (2002). the Measurement of Engagement and Burnout: a Two Sample Confirmatory Factor Analytic Approach. Journal of Happiness Studies, 3, 71-92. Retrieved from http://www.wilmarschaufeli.nl/publications/Schaufeli/178.pdf

Swarnalatha, \& Prasanna. (2013). Employee engagement: A theoretical view. International Journal of Scientific Research, 2(8), 259-262.

Tantri, F. (n.d.). The Inluence of Development Effectiveness and Education and Training Quality on The Driver' s Technical Skills of PT XYZ in Jakarta, 2(2), 169-176.

Tantri, Gunawan, \& Ruminda. (2015). The Influence of Development Effectiveness and Education and Training Quality on The Driver's Technical Skills of PT XYZ in Jakarta. Jurnal Manajemen Transportasi \& Logistik, $2(2)$ 169-176. https://doi.org/http://dx.doi.org/10.25292/j.mtl.v2i2.146

Vance. (2006). Engagement and Commitment. Alexandria: The SHRM Foundation.

Yao, Woan, Li, \& Ahmad. (2017). The Relationship between Leadership Styles and Employee Engagement: Evidences from Construction Companies in Malaysia. The Social Sciences, 12, 984-988. https://doi.org/10.3923/sscience.2017.984.988 